DOI https://doi.org/10.32405/2218-7650-2020-12(41)-180-197

Удк 37.042

Ніколенко Людмила Миколаївна,

кандидат педагогічних наук, доцент,

завідувачка кафедри педагогіки та спеціальної освіти

Дніпровського національного університету імені Олеся Гончара.

Дніпро, Україна.

ORCID ID: https://orcid.org/0000-0001-8708-3117

L.nikolenko1@gmail.com

\title{
Шилонова Вєра,
}

доктор PhD, завідувачка кафедри

спеціальної та лікувальної педагогіки

Інституту Юрая Палеша в Левочі

Католицького університету в Ружомберку.

Левоча, Словацька республіка.

ORCID iD: https://orcid.org/0000-0003-3347-925X

viera.silonova@ku.sk

\section{СПРИЯТЛИВИЙ СОЦІАЛЬНИЙ КЛІМАТ В УЧНІВСЬКОМУ ІНКЛЮЗИВНОМУ КОЛЕКТИВІ}

Анотація. У статті розглянуто стан соціального клімату в учнівському інклюзивному колективі на прикладі класних колективів других класів Жовтоводського КЗЗСО № 1, Україна. Теоретичну основу проблеми взаємодії в учнівському інклюзивному колективі склали наукові доробки вчених у галузі інклюзивної освіти. 3'ясовано, як розуміють поняття «інклюзивне навчання» вчені в Україні та за кордоном, які умови його ефективності означуються у педагогічній науці. Аналіз літератури показав, що останнім часом відбуваються докорінні зміни у розумінні явища інклюзії в усьому світі. Сьогодні поняття інклюзії в освіті розуміють більш широко: мають на увазі не лише освітню, а й соціальну інтеграцію і відносять до осіб із особливими потребами представників різних національностей, біженців та інші категорії. Це вимагає перегляду підходів до організації інклюзивного освітнього процесу, забезпечення певних умов його ефективності. На думку авторів, найважливішою умовою ефективного запровадження інклюзивного навчання $є$ створення сприятливого соціального клімату в учнівському інклюзивному колективі шляхом формування і розвитку в учнів навичок соціальної взаємодії. Представлені результати емпіричного дослідження показали, що соціальний клімат в обраних колективах доволі напружений, ближчий до несприятливого, діти з особливими освітніми потребами почувають себе емоційно неблагополучно, вони 
невпевнені в собі, тривожні, мають занижену самооцінку. Водночас, усі діти включаються в ігрову діяльність, і це дає змогу стверджувати, що саме такий вид роботи може слугувати засобом налагодження взаємин між дітьми в інклюзивному колективі. У подальшому автори планують підібрати комплекс інноваційних методів, який сприятиме формуванню і розвитку навичок соціальної взаємодії у дітей, що позитивно має позначитись на соціальному кліматі в учнівському інклюзивному колективі.

Ключові слова: інклюзія; інклюзивна освіта; інклюзивне навчання; учнівський інклюзивний колектив; навички соціальної взаємодії; сприятливий соціальний клімат; діти 3 особливими освітніми потребами (ООП).

\section{1. ВСTУП / INTRODUCTION}

Постановка проблеми. Останніми десятиліттями в усьому світі відбуваються докорінні зміни у розумінні та забезпеченні якісної освіти для дітей з особливими освітніми потребами (ООП). Одним з основних принципів міжнародних стандартів у ставленні до цієї категорії населення, яких дотримується й Україна, $є$ право на інтеграцію в суспільство, що передбачає забезпечення таким дітям рівного доступу до якісної освіти. Відповідно до здійснюваних у системі освіти України змін, станом на 2018/2019 н.р. в інклюзивних класах загальну середню освіту здобували 11866 учнів з оОП; кількість асистентів учителів в інклюзивних класах склала 7 636. Протягом останніх трьох років кількість інклюзивних класів зросла в 3,1 рази, а кількість дітей з ООП, що здобувають у них освіту, зросла в 2,8 рази [1]. Разом зі збільшенням кількості дітей, яким стало доступним інклюзивне навчання, набувають гостроти проблеми їх співіснування в учнівських колективах.

Досвід впровадження інклюзії в країнах Європи та США, пілотних проектів, реалізованих в Україні до 2017 р. (Львівська, Полтавська, Дніпропетровська та інші області) показує, що навчання дітей з оОП спільно з нормотиповими однолітками сприяє їх соціальній адаптації. Ця форма навчання $\epsilon$ корисною і для дітей з нормою розвитку, бо вони, спілкуючись і взаємодіючи з дітьми з ООП, починають розуміти проблеми і потреби оточуючих, стають добрішими. Імовірно, що навички толерантної взаємодії ці діти візьмуть у доросле життя, що позитивно вплине на гармонізацію українського суспільства загалом.

Однак, цей же досвід також показав недостатню компетентність педагогів як щодо взаємодії безпосередньо з дітьми з ООП, так і проблему щодо керівництва та налагодження сприятливої міжособистісної й 
колективної взаємодії школярів в інклюзивному класі. Педагоги не знають, як допомогти учням з ООП освоїтися в колективі, потоваришувати з однокласниками, налагодити успішне спілкування, вважають, що цим має займатись асистент вчителя, а сам педагог - навчанням нормотипових дітей. Спостереження за класами, де здобувають освіту діти з ООП, показують, що проблеми соціальних контактів знижують їх впевненість у собі, пізнавальну активність, негативно впливають на розвиток усіх психічних функцій, що у цілому негативно впливає на якість процесу їх соціалізації та освіти.

Таким чином, потреба у сприянні адаптації та соціалізації дітей із ОоП, забезпеченні рівного доступу до якісної загальної освіти усім категоріям дітей та необхідність формування гуманних стосунків в українському суспільстві загалом складають актуальність цієї статті.

Аналіз останніх досліджень і публікацій. Організації педагогічної роботи з дітьми з ООП в закладі загальної освіти останнім десятиріччям присвячено ряд праць вітчизняних науковців. Так, С. Архипова [2] вивчає питання соціального виховання дітей з ООП в умовах інклюзивного навчання і наголошує, що у його вирішенні необхідно зосередитись на формуванні соціальної зрілості й розвитку особистості дитини з ООП через включення її в різні види соціальних відносин у спілкуванні, грі, навчальній і суспільно корисній діяльності. Праці С. Миронової [3] стосуються розробки комплексного підходу до вирішення проблеми інклюзивного навчання в соціальному аспекті. Вчена розглядає підходи до реалізації інклюзивної освіти як нової соціальної моделі у світі та Україні і звертає особливу увагу на психолого-педагогічний супровід дітей в інклюзивному закладі. Результати дослідження О.Федоренко [4] показали, що у молодших школярів, які навчаються за інклюзивною формою, прослідковується низький рівень соціальної інтегрованості, натомість вони мають високі показники соціальної ізольованості, у них домінують соціальна взаємодія з дорослими, серед яких особливе місце посідають найближчі родичі та асистент педагога. Високі показники соціальної самостійності є свідченням того, що процес інтеграції у класний колектив відбувається стихійно. Дослідниця наголошує на необхідності впровадження комплексних педагогічних заходів, які сприяли б набуттю дітьми 3 ООП позитивного досвіду соціальної взаємодї 3 оточуючими. Наукові інтереси О. Чопік [5] торкаються формування взаємин дітей із ОоП в умовах інклюзивного навчання; вона наголошує, що однією 3 умов, яка забезпечує ефективність інклюзивної освіти, $\epsilon$ формування міжособистісних стосунків дітей 3 вадами психофізичного розвитку зі здоровими однолітками, тому що сьогодні багато дітей з ООП знаходяться в ситуації «псевдовключення». Суттєвим аспектом вирішення цієї проблеми $\epsilon$ 
пошук шляхів та засобів подолання перешкод у процесі взаємодії таких учнів 3 класом, де використання традиційних шляхів і методів $\epsilon$ недостатнім. У дисертації 3. Шевців [6] розглянуто розвиток інклюзивної освіти в Україні, іï законодавчу базу, яка визначає порядок організації інклюзивного навчання в загальноосвітніх навчальних закладах, а особлива увага сконцентрована на питанні підготовки вчителів до здійснення інклюзивного навчання. У рамках канадсько-українського проекту «Інклюзивна освіта для дітей з особливими потребами в Україні» А. Колупаєва та Л. Савчук [7] займалися розробкою проблеми упровадження інклюзивної моделі освіти в Україні на рівні освітніх закладів, підготовки педагогів і надання спеціальних послуг дітям з ООП та їхнім сім'ям. Серед зарубіжних досліджень проблеми інклюзивної освіти виокремлюємо також дослідження, що проводяться канадськими вченими Університету Альберта, зокрема завідувачем Всеканадської кафедри інклюзії, професором Дж. Лупарт [8].

Незважаючи на значну увагу до розв'язання проблеми інклюзивного навчання в науково-педагогічній спільноті, все ж маємо поки що більше питань, аніж відповідей. Теоретико-правові аспекти інклюзивної освіти і налагодження інклюзивного навчання дітей з ООП у цілому означені, на часі питання методології i практики їх реалізації. Звертаємо увагу на першочергове, на нашу думку і з погляду інших науковців та практиків, завдання, що постає перед педагогом в інклюзивному класі - налагодження взаємодії між дітьми, створення сприятливого клімату для кожного члена інклюзивного колективу, у якому дитина матиме змогу розвиватися.

\section{META TА ЗАВДАННЯ / AIM AND TASKS}

Mema статті - розглянути певні теоретичні аспекти сутності та ролі інклюзивного навчання у досягненні освітніх цілей Концепції нової української школи.

Відповідно до зазначеної мети у статті поставлено такі завдання: представити результати емпіричного дослідження стану соціального клімату в учнівському інклюзивному колективі.

\section{TЕОРЕТИЧНІ ОСНОВИ ДОСЛІДЖЕННЯ / THE THEORETICAL BACKGROUNDS}

Огляд теоретичних джерел з проблеми інклюзивного навчання, що постала перед педагогічною спільнотою останніми роками й активувалася законами України у сфері загальної середньої освіти, бачимо необхідним присвятити усвідомленню сутності та ролі такої форми навчання у досягненні освітніх цілей нової української школи. Насамперед хочемо зауважити, що ідеї інклюзії та упровадження в систему освіти інклюзивного навчання прийшли в 
Україну із значним запізненням (увесь світ вже 26 років активно упроваджує інклюзію, $з$ дня проголошення Саламанської декларації - засадничого документа з інклюзивної освіти, укладеного в Іспанії у 1994 році). Але це якраз дає українським вченим і педагогам можливість розбудовувати цей процес більш ефективно, використовуючи досвід багатьох країн світу, і спиратися на еволюцію у розумінні сутності інклюзії.

Так, наприкінці 90-х років XX ст. UNESCO розглядала інклюзію як підхід, що «динамічно розвивається, полягає в позитивному ставленні до різноманітності учнів і в сприйнятті індивідуальних особливостей не як проблеми, а як можливості для збагачення процесу пізнання» [9]. У нашій роботі посилаємося на оновлені погляди і підходи до інклюзії, що прозвучали на Міжнародному форумі UNESCO щодо включення та справедливості в освіту (Колумбія, м. Калі, вересень 2019 р.). У Калійських зобов'язання щодо відповідних можливостей та інклюзії в освіті подано оновлене визначення інклюзії, за яким передбачається повна залученість та доступ до освіти всіх дітей, молоді та дорослих; цінується та поважається різноманіття; визнаються неможливими будь-які форми дискримінації [10]. Освітяни різних країн i народів зійшлися у думці, що інклюзія стосується не тільки учнів 3 порушеннями психофізичного та ментального розвитку, а й представників різних національностей, регіонів, біженців, внутрішньо переміщених осіб, носіїв різних мов, представників різних віросповідань, осіб різного віку, незалежно від їхніх статків та інших можливостей.

Сучасне поняття інклюзії означає не просто доступ до освіти виключених раніше категорій громадян, а й їхню активну участь у навчальному процесі, приналежність до колективу та можливість демонструвати результати навчання. Тому можна сказати, що інклюзія - це певний спосіб організації та розбудови освітнього середовища, своєрідна філософія освіти, де $\epsilon$ місце для всіх і кожного. Інклюзія передбачає активну участь кожної дитини, незважаючи на індивідуальні особливості ії розвитку, у процесі отримання знань, культурному і суспільному житті. Вона вимагає змін і модифікацій змісту, підходів, структури і стратегії освіти з урахуванням потреб усіх дітей.

У площині нашого дослідження $є$ вагомими такі аспекти інклюзії: це постійний пошук ефективніших шляхів задоволення індивідуальних потреб усіх дітей, у якому відмінності $є$ позитивним явищем, що стимулює навчання дітей і дорослих; інклюзія передбачає присутність, участь і досягнення всіх суб'єктів педагогічного процесу, насамперед - дітей з ООП [11].

Нагальна практична потреба відповідати викликам світових освітніх тенденцій щодо інклюзії спонукає українських науковців і практиків до пошуку шляхів організації та забезпечення права на освіту та інтеграцію у 
соціум дітей з ООП. Серед вчених, котрі займаються вирішенням означеної проблеми, виокремлюємо В. Бондаря, А. Колупаєву, Н. Савінову, В. Синьова, Н. Пахомову, В. Тарасун, З. Шевців, А. Шевцова та інших. Ці науковці розробляють теоретичні засади інклюзивної освіти, визначають зміст і методи інклюзивного навчання в системі освіти України.

Для нас важливим $є$ прогресивний поступ бачення висвітлюваного явища на терені української педагогіки. Так, А. Колупаєва, котра перша в Україні здійснила докторське дослідження з проблем інклюзивної освіти (2007 р.), зазначала, що інклюзивне навчання «це система освітніх послуг, що базується на принципі забезпечення основного права дітей на освіту та права навчатися за місцем проживання, яка передбачає навчання в умовах загальноосвітнього закладу» [12, с. 44]. Академік Академії педагогічних наук України В. Бондар у 2010 р. визначив інклюзивне навчання як процес і результат включення дітей з особливостями психофізичного розвитку та дітей, які не мають таких порушень, до навчання в одному класі загальноосвітньої школи $[13$, с. 39-43]. Наведені визначення поглиблюються у Концепції розвитку інклюзивного навчання (2010р.), де це поняття трактується як «комплексний процес забезпечення рівного доступу до якісної освіти дітям з ООП шляхом організації їх навчання у загальноосвітніх навчальних закладах на основі застосування особистісно орієнтованих методів навчання, 3 урахуванням індивідуальних особливостей навчально-пізнавальної діяльності таких дітей» [14]. У подальшому дослідники цієї проблеми уточнювали розуміння феномену і представляли його як систему освітніх послуг, що базується на принципі забезпечення основного права дітей на освіту та права навчатися за місцем проживання, що передбачає навчання в умовах загальноосвітнього закладу [15], а також в умовах дошкільного, загальноосвітнього, професійного, вищого навчального закладу [16]. Із накопиченням наукових розвідок у цьому напрямі підходи до розуміння інклюзивного навчання розширилися, і це отримало відображення в оновленому Законі України «Про освіту» (2017р.): «інклюзивне навчання - це система освітніх послуг, що забезпечує реалізацію права на освіту осіб з 00П, а також їх соціалізацію та інтеграцію в суспільство...» [17].

Як бачимо, за відносно короткий час українська педагогічна наука i практика почала ширше розглядати сутність такого процесу, як інклюзивне навчання. I все ж, найближчим до нашого дослідження залишаємо розуміння UNESCO, котре передає бачення інклюзивного навчання як процесу звернення і відповіді на різноманітні потреби учнів через забезпечення їхньої участі в навчанні, культурних заходах і житті громади, та зменшення виключення в освіті та навчальному процесі [10]. 
Це визначення органічно доповнює доктор педагогічних наук З. Шевців [6]: «Інклюзивне навчання - це спеціально організований та керований навчальний процес взаємодії учителя та учнів у загальноосвітній школі загального типу, у результаті якого відбувається задоволення індивідуальних освітніх потреб усіх учнів, засвоєння знань, умінь та навичок». При цьому для школярів з ООП загальноосвітній заклад загального типу передбачає створення умов для спеціальних освітніх послуг, а для навчання нормативних дітей означає свободу вибору між інклюзивним і звичайним класом.

Зважаючи на вищенаведені тлумачення, можна сказати, що навчання зазначеної категорії учнів передбачає пристосування освітнього простору до їх індивідуальних особливостей, надання якісних освітніх послуг таким учням на основі використання особистісно орієнтованого підходу, застосування індивідуальних, групових форм роботи, що враховують міру участі в них дитини з ООП.

Останнім часом усе більше батьків дітей з ОоП бажають, щоб їхні діти навчалися та виховувалися у закладах загальної освіти. Зрозуміло, що така дитина відчуває значні труднощі у закладі загальної освіти, однак спільне навчання буде досвідом, яким вона зможе скористатися в подальшому житті. Для того, щоб такий досвід набував якомога позитивнішого характеру, необхідно (за В.Синьовим та А.Шевцовим $[18$, с. 11]) організовувати освітню інклюзію на засадах рівного доступу до навчання в загальноосвітніх закладах та отримання якісної освіти кожною дитиною; визнання здатності до навчання кожної дитини та необхідність створення суспільством відповідних умов для цього; забезпечення права дітей розвиватись у родинному оточенні та мати доступ до всіх ресурсів місцевої спільноти; залучення батьків до навчального процесу як рівноправних партнерів та перших учителів дітей; розробки навчальних програм на основі особистісно орієнтованого та індивідуального підходів, що сприяють розвитку навичок навчання протягом усього життя; визнання того факту, що інклюзивне навчання передбачає додаткові ресурси, необхідні для забезпечення особливих освітніх потреб дитини; використання результатів сучасних досліджень та практики в реалізації інклюзивної моделі навчання; реалізації командного підходу в навчанні й вихованні дітей, що передбачає залучення педагогів, батьків, спеціалістів.

Зауважимо, що модифікація шкільного середовища далеко не завжди вимагає переобладнання та пристосування приміщення. Переконані, що переважною мірою цей процес стосується соціального оточення і допомоги дитині з ООП та дітям з нормою розвитку налагодити здорове спілкування у колективі. Як зазначає А. Колупаєва [12, с.28], почуття 
приналежності $є$ дуже важливим для дітей. Тому вчитель має створювати ситуації позитивних соціальних взаємин учнів. Завдяки контактам 3 однолітками діти розвиваються емоційно і соціально, вони вчаться жити у злагоді з людьми, у них формується самоповага. Сприятливе середовище заохочує всіх дітей, незалежно від їхніх можливостей, до досліджень, ініціативи, творчості, що забезпечує успішне навчання і розвиток.

У зв'язку із зазначеним, перед педагогом (більшою мірою, аніж перед рештою спеціалістів, задіяних в інклюзивному навчанні) постають складні завдання щодо організації спільної дозвіллєвої діяльності учнів інклюзивного класу, оскільки саме в ній реально подолати відчуження дітей з ООП від соціуму. У середовищі закладу загальної середньої освіти вони не стільки бачать, скільки відчувають свою відмінність від однолітків: школярі уникають контактів або, навпаки, зачіпають i ображають таких однокласників. Часто вчителі не помічають такої поведінки дітей на перервах, або пропускають повз увагу, бо просто не знають, як діяти і не в змозі допомогти дітям. Звичайно, тут можна звернутися за допомогою до психолога, однак цей спеціаліст один на весь заклад освіти, і кілька занять, проведених ним, об'єктивно не матимуть бажаного результату. Робота в цьому напрямі має бути системною і неперервною аж до вироблення в учнів стійких навичок соціальної взаємодії. Дітям треба навчитися цінувати унікальність, здібності кожного однокласника 3 порушеннями чи без них, а допомогти їм у цьому має насамперед педагог.

Аналіз вищезазначених джерел дозволив виокремити такі важливі моменти: інклюзивна форма навчання відкрита для всіх дітей, незалежно від їхніх фізичних, соціальних чи інших особливостей, вона передбачає безбар'єрне навчальне середовище, адаптовані навчальні програми та плани, розроблені та опрацьовані методи й форми навчання та виховання, сприяння соціальному, емоційному та когнітивному розвитку кожного з учнів з тим, щоб вони відчували себе повноцінними учасниками шкільного життя.

Однак, найважливішою умовою, яка зробить можливим інклюзивному навчанню повною мірою виконувати свою роль в освіті, на нашу думку, $\epsilon$ створення сприятливого соціального клімату в учнівському інклюзивному колективі, дотримання якого дозволяє розвивати індивідуальні сильні сторони і таланти, приймати всіх дітей, без виключення, в систему загальної освіти і суспільство, працювати над досягненням індивідуальної мети дитини з ООП, будувати міцні дружні стосунки з іншими дітьми. I тут необхідно проявити креативність і застосовувати інноваційні методи, що зможуть об’єднати інтереси й можливості кожної дитини. 


\section{4. МЕTОДИ ДОСЛІДЖЕННЯ / RESEARCH METHODS}

Із метою з'ясування стану соціального клімату в учнівському інклюзивному колективі було проведено емпіричне дослідження, базою якого виступив Комунальний заклад загальної середньої освіти № 1 м. Жовті Води, Україна, де впроваджується інклюзивне навчання. Ми обрали дітей других класів, оскільки в першому класі вони навчались у закладі дошкільної освіти, а до школи прийшли в другий клас. У кожен із класів прибули діти з ООП: у 2-А клас - двоє, а в 2-Б - одна дитина. Саме тому в цих дітей адаптаційний період лише почався. Усього в дослідженні взяли участь 50 дітей (два класи по 25 осіб в кожному). Умовно визначили як експериментальну групу (ЕГ) учнів 2-А класу, і як контрольну (КГ) учнів 2-Б класу. Для діагностики показників соціального клімату дитячого колективу було використано такі методики: анкета «Клімат у колективі» (Д. Михайленко), «Мій клас» (модифікація Ю. Гільбуха), проективні малюнкові методики «Мій клас» та «Школа тварин». Під час діагностики дітям надавалася допомога у двох випадках: при нерозумінні змісту інструкції показували зразок виконання та повторювали завдання, якщо діти його забували.

\section{5. РЕЗУЛЬТАТИ ДОСЛІДЖЕННЯ / RESEARCH RESULTS}

Проведений аналіз стану соціального клімату в кожному 3 інклюзивних колективів загалом засвідчив несприятливу атмосферу для взаємодії. Результати опитування за першою анкетою показали, що діти, у яких найбільше негативних відповідей (серед них виявилися і діти з ОоП), відчувають пригнічений настрій впродовж дня, проявляють пасивність при спробі більш тісного контакту, а то й зовсім уникають таких контактів, виражають негативне ставлення до спільної діяльності. В ЕГ 80\% дітей відзначили низький ступінь сприятливості для роботи колективу. У КГ $16 \%$ дітей - доброзичливі стосунки у колективі, проте до позитивних характеристик колективу залишилися байдужими $84 \%$, а високого ступеня сприятливості не було виявлено в жодній групі. Щодо ступеня несприятливих умов для роботи колективу, то ЕГ дала такі показники: початковий - 8\%, середній - 36\% і високий - 56\%. У КГ приблизно такі ж результати. Припускаємо, що учні в обох групах бажають спілкуватися, однак, не мають досвіду та навичок такої взаємодії. Результати цього анкетування відображено у таблиці 1. 
Таблиця 1

Результати тестування за методикою «Визначення психологічного клімату в класі» (Д. Михайленко)

\begin{tabular}{|c|c|c|c|c|c|c|c|c|c|}
\hline \multirow{2}{*}{ 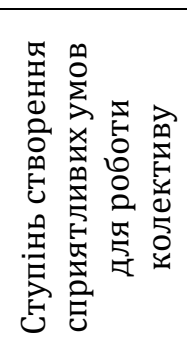 } & \multicolumn{2}{|c|}{$\mathrm{E} \Gamma$} & \multicolumn{2}{|c|}{ КГ } & \multirow[b]{2}{*}{ 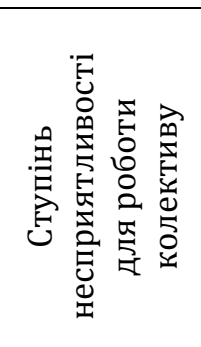 } & \multicolumn{2}{|c|}{ ЕГ } & \multicolumn{2}{|c|}{ КГ } \\
\hline & 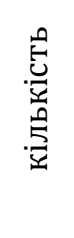 & $\partial^{\circ}$ & 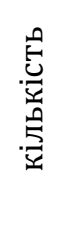 & $\partial^{\circ}$ & & 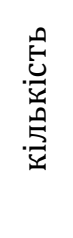 & $\partial^{\circ}$ & 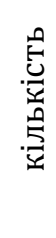 & $a^{\circ}$ \\
\hline 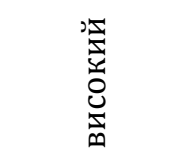 & & & & & 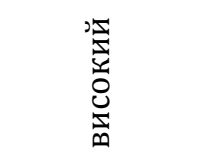 & $\stackrel{\sim}{\sim}$ & t & $\stackrel{\Xi}{\sim}$ & மீ \\
\hline 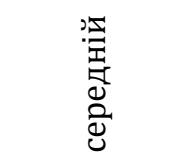 & เก & $\stackrel{\curvearrowright}{N}$ & H & $\stackrel{0}{\rightarrow}$ & 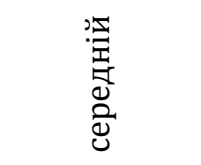 & $\infty$ & $\tilde{m}$ & $\sigma$ & $\stackrel{m}{m}$ \\
\hline 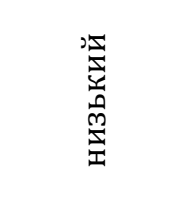 & ㄱ. & 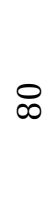 & $\vec{N}$ & ఉా & 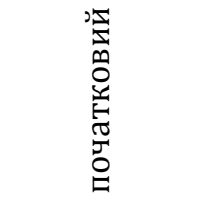 & - & $\sigma$ & $N$ & $\infty$ \\
\hline
\end{tabular}

Ми доповнили анкетування бесідою, метою якої було виявити можливі причини несприятливого клімату у колективі. Нам видалося цікавим, що жодна дитина не вказала, що має непорозуміння з батьками, деякі учні вказали на непорозуміння із вчителями (12\%), а 44\% - 3 однокласниками. Як виявило це опитування, в обох колективах майже однаковий соціальний клімат і $\epsilon$ певні проблеми, які, ми переконані, можна скоригувати.

Відповіді учасників дослідження на питання анкети «Мій клас» (методика Боврозера у модифікації Ю. Гільбуха) підтвердили результати попереднього опитування. Вважаємо необхідним зазначити, що діти обох груп вагалися з відповідями, деякі завдання потребували неодноразового повторення. Допомагало те, що ми мали змогу пояснювати дітям завдання, оскільки анкетування проводилося індивідуально (не всі діти розуміли, що прочитали, а були й такі, які ще не вміли читати). Звертаємо увагу на деякі відповіді учнів. Одним з питань анкети було про дітей у класі, 3 якими я не товаришую. Із ЕГ лише 5\% дітей вказали, що кожен учень - мій друг, що показало бажання цих дітей товаришувати з однокласниками, i водночас, що переважна більшість учнів не так позитивно налаштовані. $€$ 
діти, які завжди прагнуть настояти на своєму (25\%), що не зовсім правильно, оскільки така поведінка може призвести до конфліктів 3 іншими. Вразило й те, що чимало учнів класу люблять битися 3 однолітками (52\%). Це більше половини учнів, занадто багато, щоб залишити без уваги такий факт. I лише двоє дітей вказали, що клас веселий. Ми дійшли думки: якщо в колективі нічого не змінити, то в майбутньому будуть негативні наслідки, і ще раз переконалися, що правильно обрали середовище для нашого дослідження. Результати виконання завдань відображено у таблиці 2.

Таблиця 2

\section{Результати діагностики за методикою «Мій клас»} (модифікація Ю. Гільбуха)

\begin{tabular}{|l|c|c|c|c|}
\hline \multirow{2}{*}{ Ступінь } & \multicolumn{2}{|c|}{$\mathrm{E}$} & \multicolumn{2}{c|}{ КГ } \\
\cline { 2 - 5 } & Кількість & $\%$ & Кількість & $\%$ \\
\hline задоволеності & 8 & 32 & 9 & 36 \\
\hline конфліктності & 15 & 60 & 15 & 60 \\
\hline згуртованості & 2 & 8 & 1 & 4 \\
\hline
\end{tabular}

Проективна методика «Малюнок «Мій клас» дала змогу краще з'ясувати взаємини в класі та ставлення дітей до школи. Більшість дітей зобразили себе окремо від інших, що свідчило про нестабільність загального психологічного стану школярів. Можемо говорити навіть про емоційно неблагополучну позицію дитини, яка вказує на труднощі адаптації до перебування у класному колективі.

Проективна методика «Школа тварин» дала змогу вивчити стан взаємин у класі та з учителем, рівень тривожності та самооцінки учнів. Більше половини дітей розмістили себе ближче до верхньої частини аркушу, що трактується як висока самооцінка. тобто можна припустити, що вони не задоволені своїм становищем у колективі і прагнуть визнання 3 боку оточуючих. Ці показники збігаються із даними про те, що учні люблять битися, а отже, маємо об'єктивну картину стану соціального клімату у колективах. Контури фігур, які були в так званих «затемнених лініях», свідчили, що учні хочуть захистити себе від оточуючих.

Загалом, під час первинного обстеження за цими методиками ми спостерігали емоційно неблагополучну позицію дітей з ООП, яка вказувала на труднощі адаптації до перебування в класному колективі та невпевненість у собі, низьку самооцінку (діти розміщували себе в нижній частині аркуша), прояви тривожності (легкий натиск олівця). Результати емпіричного дослідження продемонстрували нестабільний, ближчий до несприятливого, соціальний клімату в колективах обох груп реципієнтів. 


\section{6. ВИСНОВКИ ТА ПЕРСПЕКТИВИ ПОДАЛЬШИХ ДОСЛІДЖЕНЬ / CONCLUSIONS AND PROSPECTS FOR FURTHER RESEARCH}

Отже, ми розглянули теоретичні аспекти проблеми соціальної взаємодії в учнівському інклюзивному колективі. З’ясували, як розуміють інклюзивне навчання вчені в Україні та за кордоном, які умови його ефективності означуються у педагогічній науці. Аналіз літератури щодо цього показав, що останнім часом відбуваються докорінні зміни у розумінні явища інклюзії в усьому світі. Якщо двадцять років тому, коли вперше була піднята ця проблема, говорилося про інтеграцію осіб з інвалідністю як забезпечення їм рівності у праві на освіту, то сьогодні поняття інклюзії в освіті розуміють більш широко: мають на увазі не лише освітню, а й соціальну інтеграцію і відносять до осіб із особливими потребами представників різних національностей, біженців та інші категорії. І це вимагає перегляду підходів до організації інклюзивного освітнього процесу, забезпечення певних умов його ефективності.

В Україні також набувають поширення новітні наукові погляди на порушену проблему, вчені вивчають і розробляють освітні технології, в основу яких покладено принцип урахування інтересів дітей з ООП. Відповідно до поглиблення розуміння сутності явища інклюзії, поступово змінюються підходи до вирішення проблеми інклюзивного навчання в системі освіти. Свої дослідження українські науковці грунтують на світовому досвіді у цій сфері.

На нашу думку, найважливішою умовою ефективного запровадження інклюзивного навчання $\epsilon$ створення сприятливого соціального клімату в учнівському інклюзивному колективі. Результати здійсненого емпіричного дослідження показали, що соціальний клімат в обраних колективах доволі напружений, ближчий до несприятливого, діти з ООП почувають себе емоційно неблагополучно, вони невпевнені в собі, тривожні, мають занижену самооцінку. Водночас, усі школярі більш-менш активно включалися в ігрову діяльність, що дало змогу стверджувати, що саме такий вид роботи може слугувати засобом налагодження взаємин між дітьми.

Перспективи подальших досліджень. Ми передбачаємо, що стан соціального клімату в колективі залежить від рівня розвитку навичок соціальної взаємодії учнів, і на основі цього у подальшому плануємо підібрати комплекс інноваційних методів, який сприятиме формуванню і розвитку навичок соціальної взаємодії у дітей, що позитивно має позначитись на взаєминах та якості інклюзивного навчання у цілому.

\section{7. СПИСОК ВИКОРИСТАНИХ ДЖЕРЕЛ / REFERENCES (TRANSLATED AND TRANSLITERATED)}

[1] Інклюзивне навчання: статистичні дані. [Електронний ресурс]. 
Міністерство освіти і науки України.

Доступно: https://mon.gov.ua/ua/tag/inklyuzivne-navchannya

[2] С. Архипова, та Л. Смеречак, «Особливості соціального виховання дітей з особливими освітніми потребами в умовах інклюзивного навчання», Науковий часопис Національного педагогічного університету ім. М. П.Драгоманова. Серія 11. Соціальна робота. Соціальна педагогіка, вип. 24 (1), с. 8-15, 2018. [Електронний ресурс]. Доступно: http://nbuv.gov.ua/UJRN/Nchnpu_011_2018_24(1)_4.

[3] С. Миронова, Педагогіка інклюзивної освіти. Кам'янець-Подільський, Україна: Кам'янець-Подільський нац. ун-т імені Івана Огієнка, 2016.

[4] О.Федоренко, «Особливості соціальної інтегрованості молодших школярів зі зниженим слухом в умовах інклюзивного навчання», Особлива дитина: навчання $i$ виховання, № 1, с. 79-85, 2015. [Електронний ресурс].

Доступно: http://nbuv.gov.ua/UJRN/DLog_2015_1_13.

[5] О. Чопік, «Формування взаємин дітей з вадами опорно-рухового апарату із здоровими ровесниками в умовах інклюзивного навчання», автореф. дис. канд. наук; Нац. пед. ун-т ім. М. П. Драгоманова. Київ, 2013.

[6] 3. Шевців, «Теорія та методика професійної підготовки майбутніх учителів початкової школи до роботи в інклюзивному середовищі загальноосвітнього навчального закладу», автореф. дис. д-ра наук, Рівненський держ. гуманіт. ун-т, Рівне, 2017.

[7] А. Колупаєва та Л. Савчук, Діти з особливими освітніми потребами та організація їх навчання, Київ, Україна: АТОПОЛ, 2011.

[8] Linda Allal, Moffier Lucie Lopez, Formative Assessment. Improving Learning in Secondary Classrooms. Paris, France: OECD Centre for Educational Research and Innovation, 2005.

[9] «Інклюзивна освіта: основні положення», Всеукрайнський фонд «Крок за кроком». [Електронний ресурс].

Доступно: http://ussf.kiev.ua/ie_inclusive_education/

[10] «Про головні враження 3 міжнародного освітнього форуму 3 інклюзї̈, Освіторія. [Електронний ресурс].

Доступно: https://osvitoria.media/opinions/usi-oznachaye-usi-5-

vrazhen-z-inklyuzyvnogo-forumu-unesco

[11] Н. Софій, «Концептуальні аспекти інклюзивної освіти», Інклюзивна школа: особливості організації та управління; Л. Даниленко, Ред. Київ, Україна, 2007.

[12] А. Колупаєва, Інклюзивна освіта: реалії та перспективи. Київ, Україна: САММІТ-книга, 2008. 
[13] В. Бондар, «Інклюзивне навчання та підготовка педагогічних кадрів для його реалізації», Науковий часопис НПу ім. М. П.Драгоманова. Серія: Корекційна педагогіка та психологія, вип. 19(№ 15), 2010.

[14] Міністерство освіти і науки України. (2013, Жовт. 01). Наказ № 912 «Концепція розвитку інклюзивної освіти». [Електронний ресурс]. Доступно: https://ips.ligazakon.net/document/MUS13929

[15] Л. Міщик, «Інклюзивна освіта як умова соціалізації дітей-інвалідів у процесі навчання», Збірник наукових праць Хмельницького інституту соціальних технологій університету «Україна», № 5, с. 139-142, 2012. [Електронний ресурс].

Доступно: http://nbuv.gov.ua/UJRN/Znpkhist 2012532

[16] В. Бобрицька, «Актуальні проблеми інклюзивної освіти в Україні», Педагогічний процес: теорія і практика, вип. 5/6, с.7-11, 2015 [Електронний ресурс]. Доступно: http://nbuv.gov.ua/UJRN/pptp_2015_5-6_3.

[17] Верховна Рада України. (2017, Вер. 05). Закон № 2145-VIII «Про внесення змін до Закону України "Про освіту" щодо особливостей доступу осіб з особливими освітніми потребами до освітніх послуг». [Електронний ресурс].

Доступно: https://zakon.rada.gov.ua/laws/show/2053-19.

[18] В. Синьов та А. Шевцов, «Нова стратегія розвитку корекційної педагогіки в Україні», Дефектологія, № 2, с. 6-11, 2004.

\title{
CREATING AN ENCOURAGING SOCIAL ENVIRONMENT IN THE INCLUSIVE SETTINGS
}

\author{
Liudmyla Nikolenko, \\ Candidate of Pedagogical Sciences (PhD), Docent, \\ Chairperson of the Department of Pedagogy and Special Education \\ Oles Honchar Dnipro National University. \\ Dnipo, Ukraine. \\ ORCID ID: https://orcid.org/0000-0001-8708-3117 \\ L.nikolenko1@gmail.com \\ Vera Shilonova, \\ doctor PhD, Chairperson of the Department \\ of special and curative pedagogy \\ Juraj Palesh Institute in Levoca \\ of the Catholic university in Ruzomberok. \\ Levoca, Slovakia. \\ ORCID iD: https://orcid.org/0000-0003-3347-925X \\ viera.silonova@ku.sk
}


Abstract. In the article the condition of the social climate in a student inclusive group is examined in the example of the second year classes of school № 1 in Yellow Waters city, Ukraine. The theoretical basis of the interaction in student inclusive group problem is the scientific works by scientists in the branch of inclusive education. The understanding of the concept «inclusive training» and the conditions of its efficiency in the pedagogical science are found out by the Ukrainian and foreign scientists. The analysis of the literature concerning it has shown that recently there are basic changes in understanding inclusion all over the world. If twenty years ago when this problem has been lifted for the first time, it was told about the integration of people with physical inability and ensuring their rights to education, today the inclusion concept has broader understanding: not only education, but also social integration are included, and the representatives of different nationalities, refugees and other categories are considered to be the people with special requirements. Such understanding demands the revision of the approaches to the inclusive educational process organisation, ensuring certain efficiency conditions. According to the authors, the major condition of effective introduction is the creation of a positive social climate in student inclusive group with forming and the development of social interaction skills in pupils. The presented results of empirical research have shown that the social climate in the selected groups is strained enough, it is close to an unfavourable one, the children with special educational requirements feel emotionally unsuccessful, they are lack of self-confidence, they have sense of anxiety and underestimated selfestimation. At the same time, all the children join in playing activity, and it gives an opportunity to assert that this type of co-operation can serve as the means of building relationships between the children in a inclusive group. In future the authors are planning to pick up the complex of innovative methods, that will assist forming and development of social cooperation skills for children, that must positively affect the social climate in a student inclusive group.

Keywords: inclusion; inclusive education; inclusive teaching; a student inclusive group; social co-operation skills; a social climate; the children with special educational requirements . 


\title{
БЛАГОПРИЯТНЫЙ СОЦИАЛЬНЫЙ КЛИМАТ В УЧЕНИЧЕСКОМ ИНКЛЮЗИВНОМ КОЛЛЕКТИВЕ
}

\author{
Николенко Людмила Николаевна, \\ кандидат педагогических наук, доцент, \\ заведующая кафедры педагогики и специального образования \\ Днепровского национального университета \\ имени Олеся Гончара. \\ Днепр, Украина. \\ ORCID ID: https://orcid.org/0000-0001-8708-3117 \\ L.nikolenko1@gmail.com
}

\section{Шилонова Вера,} доктор $\mathrm{PhD}$, заведующая кафедры специальной и лечебной педагогики Института Юрая Палеша в Левоче Католического университета в Ружомбероке.

Левоча, Словацкая республіка.

ORCID iD: https://orcid.org/0000-0003-3347-925X

viera.silonova@ku.sk

Аннотация. В статье рассмотрено состояние социального климата в ученическом инклюзивном коллективе на примере классных коллективов вторых классов учреждения общего среднего образования № 1 г. Желтые Воды, Украина. Теоретическую основу проблемы взаимодействия в ученическом инклюзивном коллективе составили научные труды ученых в отрасли инклюзивного образования. Выяснено понимание понятия «инклюзивное обучение» учеными в Украине и за рубежом. Анализ литературы показал, что в последнее время происходят коренные изменения в понимании инклюзии во всем мире. Сегодня понятие инклюзии в образовании понимают более широко: имеют в виду не только образовательную, но и социальную интеграцию и к лицам с особенными потребностями относят представителей разных национальностей, беженцев и другие категории. Такое понимание требует пересмотра подходов к организации инклюзивного образовательного процесса, обеспечения определенных условий его эффективности. По мнению авторов, важнейшим условием эффективного внедрения инклюзивного обучения является создание благоприятного социального климата в ученическом инклюзивном коллективе путем формирования и развития у учеников навыков социального взаимодействия. Представленные результаты эмпирического исследования показали, что социальный климат в избранных коллективах достаточно напряжен, более близок к неблагоприятному, дети с особенными образовательными 
потребностями чувствуют себя эмоционально неблагополучно, они неуверены в себе, тревожны, имеют заниженную самооценку. В то же время, все дети включаются в игровую деятельность, и это дает возможность утверждать, что именно такой вид взаимодействия может служить средством налаживания взаимоотношений между детьми в инклюзивном коллективе. В дальнейшем авторы планируют подобрать комплекс инновационных методов, который будет способствовать формированию и развитию навыков социального взаимодействия в ученическом инклюзивном коллективе.

Ключевые слова: инклюзия; инклюзивное образование; инклюзивное обучение; ученический инклюзивный коллектив; навыки социального взаимодействия; социально-психологический климат; дети с особенными образовательными потребностями.

\section{REFERENCES (TRANSLATED AND TRANSLITERATED)}

[1] Inkliuzyvne navchannia: statystychni dani. [Elektronnyi resurs]. Ministerstvo osvity i nauky Ukrainy.

Dostupno: https://mon.gov.ua/ua/tag/inklyuzivne-navchannya

[2] S. Arkhypova, ta L. Smerechak, «Osoblyvosti sotsialnoho vykhovannia ditei $\mathrm{z}$ osoblyvymy osvitnimy potrebamy $\mathrm{v}$ umovakh inkliuzyvnoho navchannia», Naukovyi chasopys Natsionalnoho pedahohichnoho universytetu im. M. P. Drahomanova. Seriia 11. Sotsialna robota. Sotsialna pedahohika, vyp. 24(1), s. 8-15, 2018. [Elektronnyi resurs]. Dostupno: http://nbuv.gov.ua/UJRN/Nchnpu_011_2018_24(1)_4.

[3] S. Myronova, Pedahohika inkliuzyvnoi osvity. Kamianets-Podilskyi, Ukraina: Kamianets-Podilskyi nats. un-t imeni Ivana Ohiienka, 2016.

[4] O. Fedorenko, «Osoblyvosti sotsialnoi intehrovanosti molodshykh shkoliariv zi znyzhenym slukhom v umovakh inkliuzyvnoho navchannia», Osoblyva dytyna: navchannia i vykhovannia, № 1, s. 79-85, 2015. [Elektronnyi resurs]. Dostupno: http://nbuv.gov.ua/UJRN/DLog_2015_1_13.

[5] O. Chopik, «Formuvannia vzaiemyn ditei z vadamy oporno-rukhovoho aparatu iz zdorovymy rovesnykamy $\mathrm{v}$ umovakh inkliuzyvnoho navchannia», avtoref. dys. kand. nauk, Nats. ped. un-t im. M. P. Drahomanova. Kyiv, 2013.

[6] Z. Shevtsiv, «Teoriia ta metodyka profesiinoi pidhotovky maibutnikh uchyteliv pochatkovoi shkoly do roboty $\mathrm{v}$ inkliuzyvnomu seredovyshchi zahalnoosvitnoho navchalnoho zakladu», avtoref. dys. d-ra nauk, Rivnenskyi derzh. humanit. un-t, Rivne, 2017.

[7] A. Kolupaieva ta L. Savchuk, Dity z osoblyvymy osvitnimy potrebamy ta orhanizatsiia yikh navchannia, Kyiv, Ukraina: ATOPOL, 2011.

[8] Linda Allal, Moffier Lucie Lopez, Formative Assessment. Improving 
Learning in Secondary Classrooms. Paris, France: OECD Centre for Educational Research and Innovation, 2005.

[9] «Inkliuzyvna osvita: osnovni polozhennia», Vseukrainskyi fond «Krok za krokom». [Elektronnyi resurs].

Dostupno: http://ussf.kiev.ua/ie_inclusive_education/

[10] «Pro holovni vrazhennia z mizhnarodnoho osvitnoho forumu z inkliuzii», Osvitoriia. [Elektronnyi resurs].

Dostupno: https://osvitoria.media/opinions/usi-oznachaye-usi-5vrazhen-z-inklyuzyvnogo-forumu-unesco

[11] N.Sofii, «Kontseptualni aspekty inkliuzyvnoi osvity», Inkliuzyvna shkola: osoblyvosti orhanizatsii ta upravlinnia; L. Danylenko, Red. Kyiv, Ukraina, 2007.

[12] A. Kolupaieva, Inkliuzyvna osvita: realii ta perspektyvy. Kyiv, Ukraina: SAMMIT-knyha, 2008.

[13] V. Bondar, «Inkliuzyvne navchannia ta pidhotovka pedahohichnykh kadriv dlia yoho realizatsii», Naukovyi chasopys NPU im. M. P. Drahomanova. Seriia: Korektsiina pedahohika ta psykholohiia, vyp. 19(№ 15), 2010.

[14] Ministerstvo osvity i nauky Ukrainy. (2013, Zhovt. 01). Nakaz № 912 «Kontseptsiia rozvytku inkliuzyvnoi osvity». [Elektronnyi resurs]. Dostupno: https://ips.ligazakon.net/document/MUS13929

[15] L. Mishchyk, «Inkliuzyvna osvita yak umova sotsializatsii ditei-invalidiv u protsesi navchannia», Zbirnyk naukovykh prats Khmelnytskoho instytutu sotsialnykh tekhnolohii universytetu «Ukraina», № 5, s. 139-142, 2012. [Elektronnyi resurs].

Dostupno: http://nbuv.gov.ua/UJRN/Znpkhist 2012532

[16] V. Bobrytska, «Aktualni problemy inkliuzyvnoi osvity v Ukraini», Pedahohichnyi protses: teoriia i praktyka, vyp.5/6, s.7-11, 2015 [Elektronnyi resurs]. Dostupno: http://nbuv.gov.ua/UJRN/pptp_2015_5-6_3.

[17] Verkhovna Rada Ukrainy. (2017, Ver. 05). Zakon № 2145-VIII «Pro vnesennia zmin do Zakonu Ukrainy "Pro osvitu" shchodo osoblyvostei dostupu osib z osoblyvymy osvitnimy potrebamy do osvitnikh posluh». [Elektronnyi resurs].

Dostupno: https://zakon.rada.gov.ua/laws/show/2053-19.

[18] V. Synov ta A. Shevtsov, «Nova stratehiia rozvytku korektsiinoi pedahohiky v Ukraini», Defektolohiia, № 2, s. 6-11, 2004.

Стаття надійшла до редакції 26 березня 2020 року 